\title{
Chemical Composition of Volatile Oil of Ferula Assafoetida L
}

\author{
P. Estekhdami ${ }^{1^{*}}$, A. Nasiri Dehsorkhi ${ }^{2}$ \\ ${ }^{I}$ M.sc. Agronomy, Shahroud of University in Iran (2008). \\ ${ }^{2}$ Ph.D. student of Agroecology, Agronomy Department, Agricultural Faculty, University of Zabol, in \\ Iran. \\ *Corresponding Author: P. Estekhdami, M.Sc. Agronomy, Shahroud of University in Iran (2008).
}

\begin{abstract}
Asafoetida is an oleo-gum-resin obtained from the exudates of the roots of the Iranian endemic medicinal plant, F. asafoetida. It is used widely all over the world as a flavoring spice in a variety of foods. was analysed by GC and GC/MS. The constituents were identified by their mass spectra and Kovats' indices. Among those, The main constituents were (E)-1-propenyl sec-butyl disulfide (58.9\%), (Z)- $\beta$-ocimene (11.9\%), (E)-B-ocimene (9.0\%), $\beta$-pinene (5.0\%) and (Z)-1-propenyl sec-butyl disulfide (3.9\%).
\end{abstract}

Keywords: Asafoetida, GC/MS

\section{INTRODUCTION}

The genus Ferula, the third largest genus of the Apiaceae (alt.Umbelliferae) family,is composed of ca. 180 species (Yaqoob and Nawchoo, 2016), 15 of whichare endemic to Iran (Mozaffarian, 1996),nine species to Turkey, seven to China (Yaqoob and Nawchoo, 2016) and one species to Italy, and the rest are indigenousentities of several other countries. The majority of the Ferula plants have a pungent odor and can beused for different purposes.In the literature, numerous reports have described various biological and medicinal activities for different essential oils and ex-tracts of the Ferula plants. These include anticancer (Paydar et al., 2013;Perveen et al., 2017; Upadhyay et al., 2017), anthelmintic (Upadhyay et al., 2017), anti-epileptic (Sayyah et al., 2001;Kiasalari et al., 2013), aphicidal, antioxidant (Paydar et al., 2013;Amiri, 2014; Yusufoglu et al .2015,c;Zhang et al., 2015;Nguir et al., 2016), antimicrobial (Yang et al.,2007;Kavoosi et al., 2013; Paydar et al., 2013; Bashir et al., 2014b), antihypertensive (Ghanbariet al., 2012), antifungal (Bashiret al., 2014b;Upadhyay et al., 2017), antidepressant (Mohammadhosseini, 2016), phytotoxic (Bashir et al., 2014b), (Paydar et al., 2013), antiproliferative (Poli et al., 2005;Moradzadeh et al., 2017), acetylcholinesterase in-hibitory and muscarinic receptors inhibitory, antiprotozoal activity (Bafghi et al., 2014;Barati et al., 2014), antihemolytic antimycobacterial anti-ulcer (Alqasoumi et al., 2011), antitumor (Zhang et al., 2015;Bagheriet al., 2017), anticoagulant (Fraigui et al., 2002), antifertility, antispasmodic (Fatehi et al., 2004;Upadhyay et al., 2017), anticonvulsant (Sayyah and Mandgary, 2003;Bagheri et al., 2014b), relaxant, antinociceptive (Bagheri et al., 2014a), hypnotic (Abbasnia and Aeinfar, 2016), hypotensive (Upadhyay et al., 2017), muscle relaxant Upadhyay et al., 2017), memory enhancing (Upadhyay et al., 2017) ,enhancing digestive enzyme (Upadhyay et al., 2017), antiviral (Lee et al., 2009; Ghannadi et al., 2014;Upadhyay et al., 2017), anxiolytics (Upadhyay et al., 2017), antihyperlipidemic (Yusufoglu et al., 2015a,b),antigenotoxic (Hu et al., 2009), anti-in-flammatory (Paydar et al., 2013; Bagheri et al,. 2015), cytotoxic antihyperglycemic (Yusufoglu et al., 2015a,b;Yusufoglu et al., 2015c), acaricidal (Fatemikia et al., 2017), antidiabetic (Yarizade et al., 2017), hepatoprotective (Upadhyay et al., 2017) and antibiotic modulation (Paydar et al., 2013) activities. In this paper, chemical com- position of the essential oil, specie Ferula described.

\section{MATERIAL}

\subsection{Plant Material}

Samples of Ferula Assafoetida were collected during in May, 2013. The dried aerial parts were submitted to Hydro distillation for $3 \mathrm{~h}$ using Clevenger type apparatus, according to the European Pharmacopoeia ${ }^{5}$. The essential oil was collected, dried over anhydrous sodium sulphate and stored at $4^{\circ} \mathrm{C}$ until used. 


\subsection{Gas Chromatography}

Essential oil samples $(0.1 \mu \mathrm{L})$ were injected neat into an HP 6890 gas chromatography equipped with a flame ionisation detector (FID) and a $30 \mathrm{~m}$ x $0.25 \mathrm{~mm}$ HP-5 (cross-linked Phynel-Methyl Siloxane) column with $0.25 \mu \mathrm{m}$ film thickness (Agilent), was used for the study. Helium was used as carrier gas, the flow through the column was $1,4 \mathrm{~mL} \mathrm{~min}^{-1}$ and the splitless mode was used. The column was maintained at $40^{\circ} \mathrm{C}$ for $5 \mathrm{~min}$, increased to $230^{\circ} \mathrm{C}$ at rate of $10^{\circ} \mathrm{C} \mathrm{min}-1$ and finally raised from 230 to 280 at rate of $30^{\circ} \mathrm{C} \mathrm{min}-1$.

\subsection{Mass Spectrometry Analysis}

The oil was analysed by gas chromatography-mass spectrometry (GC-MS) using a Hewlett Packard 6890 mass selective detector coupled with a Hewlett Packard 6890 gas chromatograph. The MS operating parameters were as follows: ionisation potential, $70 \mathrm{eV}$; ionisation current, $2 \mathrm{~A}$; ion source temperature, $200^{\circ} \mathrm{C}$, resolution, 1000 . Mass unit were monitored from 30 to $450 \mathrm{~m} / \mathrm{z}$. Identification of components in the oil was based on retention indices relatives to n-alkanes and computer matching with the WILLEY275.L library, as well as by comparison of the fragmentation patterns of mass spectra with those reported in the lite rature (Adams, 1995).

\section{RESULTS}

\subsection{Chemical Composition of the Essential Oil}

Essential oil yield was $1.0 \%$. Freshly isolated essential oil was a yellow liquid with intensive, narcotic odour. The components of essential oil were separated into five classes, which were monoterpene hydrocarbons, oxygenated monoterpenes, sesquiterpene hydrocarbons, oxygenated sesquiterpenes and others (Table I). Based on GC and GC-MS analysis of the essential oil of Ferula Assafoetida 40 components were identified. An analysis of asafoetida shows of constituents were identified by their mass spectra and 40 compounds were identified representing $95 \%$ of total oil composition. The main constituents were (E)-1-propenyl sec-butyl disulfide (58.9\%), (Z)- $\beta$-ocimene (11.9\%), (E)- $\beta$-ocimene (9.0\%), $\beta$-pinene (5.0\%) and (Z)-1-propenyl sec-butyl disulfide (3.9\%) (Table I).

Table1. Chemical composition of Ferula Assafoetida L.

\begin{tabular}{|c|c|c|c|}
\hline Peak number & Compounda & Retention index & Percentage \\
\hline 1 & $\alpha$-Pinene & 1032 & 0.97 \\
\hline 2 & $\alpha$-Thujene & 1035 & 0.07 \\
\hline 3 & $\alpha$-Fenchene & 1070 & 0.02 \\
\hline 4 & Camphene & 1076 & 0.32 \\
\hline 5 & $\beta$-Pinene & 1118 & 5 \\
\hline 6 & Sabinene & 1132 & 0.72 \\
\hline 7 & Thuja-2,4(10)-diene & 1137 & 0.8 \\
\hline 8 & $\delta$-3-Carene & 1159 & 3.83 \\
\hline 9 & Myrcene & 1175 & 0.09 \\
\hline 10 & $\alpha$-Phellandrene & 1176 & 9 \\
\hline 11 & $\alpha$-Terpinene & 1188 & 0.47 \\
\hline 12 & Limonene & 1204 & 0.9 \\
\hline 13 & $\beta$-Phellandrene & 1218 & 0.02 \\
\hline 14 & (Z)- $\beta$-Ocimene & 1246 & 11.9 \\
\hline 15 & $\gamma$-Terpinene & 1255 & 0.95 \\
\hline 16 & (E)- $\beta$-Ocimene & 1266 & 9 \\
\hline 17 & (E)-1-propenyl sec-butyl disulfide & 1280 & 58.9 \\
\hline 18 & Isoterpinolene & 1236 & 0.26 \\
\hline 19 & Terpinolene & 1290 & 0.17 \\
\hline 20 & $\gamma$-Campholene aldehyde & 1477 & 0.06 \\
\hline 21 & trans-Sabinene hydrate & 1451 & 0.67 \\
\hline 22 & Longipinene & 1482 & 0.10 \\
\hline 23 & Fenchyl acetate & 1464 & 0.18 \\
\hline 24 & Citronellal & 1487 & 0.09 \\
\hline 25 & Cyclosativene & 1485 & 9.08 \\
\hline 26 & $\alpha$-Ylangene & 1493 & 0.18 \\
\hline
\end{tabular}




\begin{tabular}{|c|c|c|c|}
\hline \multicolumn{2}{|c|}{$\alpha$-Copaene } & 1497 & 0.08 \\
\hline 27 & $\alpha$-Campholene aldehyde & 1500 & 0.06 \\
\hline 28 & Decanal & 1506 & 0.07 \\
\hline 30 & Longicyclene & 1497 & 0.65 \\
\hline 31 & Cyperene & 1528 & 0.06 \\
\hline 32 & $\alpha$-Gurjunene & 1545 & 0.02 \\
\hline 33 & $\beta$-Cubebene & 1549 & 1.79 \\
\hline 34 & Linalool & 1553 & 0.50 \\
\hline 35 & cis-Sabinene hydrate & 1571 & 0.72 \\
\hline 36 & trans-p-Menth-2-en-1-ol & 1573 & 0.08 \\
\hline 37 & Pinocarvone & 1586 & 0.03 \\
\hline 38 & $1,7-$ Diepi- $\beta$-cedrene & 1562 & 0.07 \\
\hline 39 & Aristolene & 1565 & 0.06 \\
\hline 40 & (Z)-1-propenyl sec-butyl disulfide & 1592 & 3.9 \\
\hline
\end{tabular}

\section{DISCUSSION}

Ferula has many applications in Iranian folk medicine such as preservation of meat and oil and treatment of ulcer, but there are no studies proving their uses. Previous studies on chemical composition of essential oil of other specie of genu Ferula including F. ovina (Ghannadi et al., 2002). Composition of the essential oil of Ferula ovina (Boiss.) , F. cummunis (Chibani et al., 2011 ). F. gummosa (Sayyah et al., 2001). Antiepileptic potential and composition of the fruit essential oil of Ferula gummosa Boiss similarly indicated that monoterpene fractions were the main constituents of essential oils (76.2, 81.7, and $75.9 \%$ of essential oils, respectively). The main component in flower, leaf, and the stem are dllimonene $(25.04 \%), \beta$-pinene $(13.87 \%)$, and $\alpha$-terpinyl isobutyrate $(8.69 \%)$, respectively, which are different from the main compounds of other Ferula species essential oils like F. ovina, F. cummunis, and F. gummosa. It was found that monoterpene hydrocarbons were the most abundant compounds in the essential oils from flower $(81.19 \%)$ and leaf $(55.09 \%)$, while oxygenated monoterpenes were the main constituents of the essential oil from stem (61.69\%) (Ozek et al, 2008) Composition and antimicrobial activity of the oils of Ferula szowitsiana DC. From Turkey showed that the essential oil of F. szowitsiana inhibited the growth of both Gram-positive and Gram-negative bacteria and its major constituents were $\beta$-eudesmol, $\alpha$-eudesmol, and $\alpha$-pinene. Abedi et al. ( Abedi, 2008) Composition and antimicrobial activity of oleogumresin of Ferula gumosa Bioss. essential oil using Alamar blue reported that F. gummosa essential oil was contained about $88 \%$ monoterpene hydrocarbons and the main constituents were sabinene, $\beta$-pinene, and $\alpha$-pinene. The MIC values of F. gummosa essential oil against some pathogenic bacteria (S. aureus $3.125 \mu \mathrm{L} / \mathrm{mL}$ and P. aeruginosa $50 \mu \mathrm{L} / \mathrm{mL}$ ) were comparable with the MICs of F. cupularis essential oils. Previous studies showed that the essential oils from F. badrakema (Asili et al., 2009 ) Identification of essential oil components of Ferula badrakema fruits by GC-MS and 13C-NMR methods and evaluation of its antimicrobial activity F. latisecta (Iranshahi et al., 2008b) High content of polysulphides in the volatile oil of Ferula latisecta rech. F. et Aell. fruits and antimicrobial activity of the oil and Ferula assafoetida (Kavoosi et al., 2013 ) Evaluation of antioxidant and antimicrobial activities of essential oils from Carum copticum seed and Ferula assafoetida latex were moderately active against Gram-positive bacteria (S. aureus and Bacillus cereus), but Gramnegative bacteria (E. coli and P. aeruginosa) were not susceptible to the essential oils of these plants. Results of this study showed that the essential oil from stem of F. cupularis inhibited the growth of all t+est bacteria at lower MIC values than essential oils of flower and leaf parts. This may be due to its high content of oxygenated monoterpene hydrocarbons (Kotan et al., 2007).

\section{REFERENCES}

[1] Abedi, D., Jalali, M., Asghari, G., Sadeghi, N., 2008. Composition and antimicrobial activity of oleogumresin of Ferula gumosa Bioss. Essential oil using Alamar blue. Res Pharm Sci 3:41-5.

[2] Adams, R.P., 1995.Identification of Essential Oil Components by GC-MS. Allured Publication Corp., Carlo Stream, IL.

[3] Amiri, H., 2014. Chemical composition and antioxidant activity of essential oil and me- thanolic extracts of Ferula microcolea (Boiss.) Boiss (Apiaceae). Int. J. Food Prop. 17: 723-730.

[4] Asili, J., Sahebkar, A., Fazzly Bazzaz, BS., et al. 2009. Identification of essential oil components of Ferula badrakema fruits by GC-MS and 13C-NMR methods and evaluation of its antimicrobial activity. J Essent Oil Bear Plants 12:7-15. 
[5] Alqasoumi, S., Al-Dosari, M., Al-Howiriny, T., Al-Yahya, M., Al-Mofleh, I., Rafatullah, S.,2011. Gastric antiulcer activity of a pungent spice Ferula assafoetida L. in rats. Farmacia 59: 750-759.

[6] Bagheri, S.M., Abdian-Asl, A., Moghadam, M.T., Yadegari, M., Mirjalili, A., Zare- Mohazabieh, F., Momeni, H., 2017. Antitumor effect of Ferula assa foetida oleo gum resin against breast cancer induced by 4T1 cells in BALB/c mice. J. Ayurveda Integr. Med. 8: 152-158.

[7] Bafghi, A.F., Bagheri, S.M., Hejazian, S.H., 2014. Antileishmanial activity of Ferula assa- foetida oleo gum resin against Leishmania major: An in vitro study. J. Ayurveda Integr. Med. 5: 223-226.

[8] Bagheri, S.M., Hedesh, S.T., Mirjalili, A., Dashti-R, M.H., 2015. Evaluation of anti-in- flammatory and some possible mechanisms of antinociceptive effect of Ferula assa foetida oleo gum resin. J. Evid. Complement. Altern. Med. 21: 271-276.

[9] Bagheri, S.M., Dashti-R, M.H., Morshedi, A., 2014a. Antinociceptive effect of Ferula assa- foetida oleogum-resin in mice. Res. Pharm. Sci. 9: 207-212

[10] Bagheri, S.M., Rezvani, M.E., Vahidi, A.R., Esmaili, M., 2014b. Anticonvulsant effect of Ferula assafoetida oleo gum resin on chemical and amygdala-kindled rats. N. Am. J .Med. Sci. 6: 408-412.

[11] Bashir, S., Alam, M., Ahmad, B., Aman, A., Ali, J., 2013. Screening of Ferula narthex Boiss crude methanolic extract for analgesic, gastrointestinal motility and insecticidal ac -tivity. Middle East J. Sci. Res. 14:471-475.

[12] Bashir, S., Alam, M., Adhikari, A., Shrestha, R.L., Yousuf, S., Ahmad, B., Parveen, S,. Aman, A., Iqbal Choudhary, M., 2014a. New antileishmanial sesquiterpene cou -marins from Ferula narthex Boiss. Phytochem. Lett. 9: 46-50.

[13] Bashir, S., Alam, M., Ahmad, B., Aman, A., 2014b. Antibacterial, anti-fungal and phyto- toxic activities of Ferula narthex Boiss. Pak. J. Pharm. Sci. 27, 1819-1825.

[14] Fatehi, M., Farifteh, F., Fatehi-Hassanabad, Z., 2004. Antispasmodic and hypotensive effects of Ferula asafoetida gum extract. J. Ethnopharmacol. 91: 321-324.

[15] Bedir, E., Erel, Ş.B., Öztürk, B., 2015c. Antioxidant and antihyperglycemic effects of Ferula durdeana and Ferula huber-morathii in experimental diabetic rats. Int. J .Pharmacol. 11: 738-748.

[16] Caglioti, L., Naef, H., Arigoni, D., Jeger, O., 1959. Sesquiterpenes and azulenes. CXXVII. The constituents of asafetida. II. Farnesiferol B and C. Helv Chim Acta. 42:2557-70.

[17] Craft, BD., Kosinska, A., Amarowicz, R., Pegg, RB., 2010. Antioxidant properties of extracts obtained from raw, dry- roasted, and oil-roasted US peanuts of commercial importance. Plant Foods Hum Nutr. 65: 311.

[18] Chibani, S., Berhail-Boudouda, H., Kabouche, A., et al. 2011. Analysis of the essential oil of Ferula communis L. from Constantine, Algeria. Int J Med Arom Plants 1:41-44.

[19] Dehpour, AA., Ebrahimzadeh, MA., Nabavi, SF., Nabavi, SM., 2009.Antioxidant activity of the methanol extract of Ferula assafoetida and its essential oil composition.Grasas Y Aceites, 60: 405 .

[20] Fatehi, M., Farifteh, F., Fatehi- Hassanabad, Z., 2004.Antispasmodic and hypotensive effects of Ferula asafoetida gum extract. J Ethnopharmacol.91:321-4.

[21] Fujita, M., Furuya, T., Itokawa, H.,1958. Crude drugs containing coumarins and their derivatives. III. Chromatographic separation and determination of umbelliferone and its homologs. Yakugaku Zasshi. 78:395-8.

[22] Ghanbari, M., Zahedi Khorasani, M., Vakili, A., 2012. Acute and chronic effects of Ferul Kodzhimatov, O.K., Ashurmetov, O., 2002. Sesquiterpenes from Ferula penninervis.J. Nat. Prod. 65: 1897-1903.

[23] Ghannadi, A., Sajjadi, SE., Beigihasan, A., 2002. Composition of the essential oil of Ferula ovina (Boiss.) Boiss. from Iran. Daru J Pharm Sci 10:165-167.

[24] Hudaib, M., Speroni, E., Di Pietra, A.M., and Cavrini, V., 2002. GC/MS evaluation of thyme (Thymus vulgaris L.) oil composition and variations during the vegetative cycle. J. Pharm. Biom. Annl., 29: 691-700.

[25] Iranshahi, M., Hassanzadeh-Khayat, M., Bazzaz, BSF., et al. 2008b. High content of polysulphides in the volatile oil of Ferula latisecta rech. F. et Aell. fruits and antimicrobial activity of the oil. J Essent Oil Res. 20:183-5.

[26] Jordán, M.J., Martínez, R.M., Cases, M.A., and Sotomayor, J.A.,2003. Watering level effect on Thymus hyemalis Lange essential oil yield and composition. J. Agric. Food Chem., 51: 5420-5427.

[27] Kavoosi, G., Tafsiry, A., Ebdam, AA., Rowshan, V., 2013. Evaluation of antioxidant and antimicrobial activities of essential oils from Carum copticum seed and Ferula assafoetida latex. J Food Sci 78:T356-361.

[28] Khalatbary, AR., Ahmadvand, H., Effect of oleuropein on tissue myeloperoxidase activity in Experimental spinal cord trauma.Iran Biomed J., 1: 164-167. 
[29] Mahran, GH., El Alfy, TS.,1973. Ansari SM. A phytochemical study of volatile oil of Afghanian asafetida. Bull Fac Pharm Cairo Univ. 12:101-7.

[30] Mahran, GH., El-Alfy, TS., Ansary HA. 1975.A phytochemical study of the gum and resin of Afghanian asafoetida. Bull Fac Pharm; 12:119-32.

[31] Mohammad hosseini, M., 2019.et al. Industrial Crops \& Products 129. 350-394

[32] Nassar, MI., 1994. Spectral study of farnesiferol B from Ferula assafoetida L. Pharmazie. 49:542-3.

[33] Nguir, A., Mabrouk, H., Douki, W., Ben Ismail, M., Ben Jannet, H., Flamini, G., Hamza, M.A., 2016. Chemical composition and bioactivities of the essential oil from different organs of Ferula communis L. growing in Tunisia. Med. Chem. Res. 25: 515-525.

[34] Noroozi, S., Mosaffa, F., Soltani, F., Iranshahi, M., Karimi, G., Malekaneh, M., Haghighi, F., Behravan, J., 2009. Antigenotoxic effects of the disulfide compound persicasulfide A (PSA) on rat lymphocytes exposed to oxidative stre ss. Planta Med. 75:32-36.

[35] Ozek, G., Ozek, T., Iscan, G., Baser, KHC., Duran, A., Hamzaoglu, E., 2008. Composition and Antimicrobial Activity of the Oils of Ferula szowitsiana DC from Turkey. J Essent Oil Res 20:186-190.

[36] Paydar, M., Wong, Y.L., Abdulkarim Moharam, B., Movahed, E., Fen Wong, W., Yeng Looi, C., 2013. Pharmacological activities and chemical constituents of Ferula szo -witsiana DC. J. Med. Sci. 13: $236-243$.

[37] Perveen, I., Raza, M.A., Iqbal, T., Naz, I., Sehar, S., Ahmed, S., 2017. Isolation of antic- ancer and antimicrobial metabolites from Epicoccum nigrum; endophyte of Ferula sumbul. Microb. Pathog. 110: 214-224.

[38] Poli, F., Appendino, G., Sacchetti, G., Ballero, M., Maggiano, N., Ranelletti, F.O., 2005. Antiproliferative effects of daucane esters from Ferula communis and F. arrigonii on

[39] Rajanikanth, B., Ravindranath, B., Shankaranarayana, ML., 1984. Volatile polysulphides of asafoetida. Phytochemistry; 23:899-900.

[40] Ramadan, NI., Al Khadrawy, FM., 2003.The in vitro effect of Assafoetida on Trichomonas vaginalis. J Egypt Soc Parasitol. 33:615-30.

[41] Shankaranarayana, ML., Raghavan, B., Natarajan, CP., 1982.Odorous compounds of asafetida. VII. Isolation and identifi cation. Indian Food Pack. 36:65-76.

[42] Sayyah, M., Kamalinejad, M., Bahrami Hidage, M., Rustaiyan, A., 2001. Antiepileptic potential and composition of the fruit essential oil of Ferula gummosa Boiss. Iran Biomed J 5:69-72.

[43] Soobrattee, MA., Neergheen, VS., Luximon, Ramma, A., Aruoma, OI., Bahorun, T., 2005. Phenolics as potential antioxidant therapeutic agents: mechanism and actions. Mutat Res .200: 513- 579.

[44] Tavafi, M., Ahmadvand, H., 2011.Effect of rosmarinic acid on inhibition of gentamicin induced nephrotoxicity inrats. Tissue Cell.43: 392.

[45] Upadhyay, P.K., Singh, S., Agrawal, G., Vishwakarma, V.K., 2017. Pharmacological ac- tivities and therapeutic uses of resins obtained from Ferula asafoetida Linn.: A review. Int. J. Green Pharm. 11: S240.

[46] Yang, J.R., An, Z., Li, Z.H., Jing, S., Qin, H.L., 2006. Sesquiterpene coumarins from the roots of Ferula sinkiangensis and Ferula teterrima. Chem. Pharm. Bull. (Tokyo). 54: 1995-1998.

[47] Yang, L., Zhao, H.Q., Yao, G., Cai, Z., Wang, J.M., 2007. The preliminary study of anti- bacterial effect of five kinds of bacterials of Ferula sinkiangensis. J. Tradit. Chin. Med 33:53-54.

[48] Yaqoob, U., Nawchoo, I.A., 2016. Distribution and taxonomy of Ferula 1.: a review. Res. Rev. J. Bot. 5: $15-23$.

[49] Yaqoob, U., Nawchoo, I.A., 2017a. Conservation and Cultivation of Ferula jaeschkeana Vatke: A species with deep complex morphophysiological dormancy. Proc. Natl. Acad. Sci. India Sect. B - Biol. Sci. 87: 315-325.

[50] Yaqoob, U., Nawchoo, I.A., 2017b. Impact of habitat variability and altitude on growth dynamics and reproductive allocation in Ferula jaeschkeana Vatke. J. King Saud Univ. Sci. 29: 19-27.

[51] Yousefi, M., Mohammadi, M., Habibi, Z., Shafiee, A., 2010. New polysulphanes from aerial parts of Ferula behboudiana Rech. f. Esfand. Nat. Prod. Res. 24: 1352-1357.

[52] Yousefi, M., Mohammadi, M., Habibi, Z., 2011. Disulphides in the volatile oil of Ferula behboudiana Rech. f. \& Esfand. Nat. Prod. Res. 25: 1629-1634.

[53] Yusufoglu, H.S., Soliman, G.A., Abdel-Rahman, R.F., Abdel-Kader, M.S., Ganaie, M.A,. Bedir, E., Baykan, S., Oztürk, B., 2015a. Antihyperglycemic and antihyperlipidemic effects of Ferula duranii in experimental type 2 diabetic rats. Int. J. Pharmacol. 11: 532-541.

[54] Yusufoglu, H.S., Soliman, G.A., Abdel-Rahman, R.F., Abdel-Kader, M.S., Ganaie, M.A,. Bedir, E., Erel, Ş.B., Öztürk, B., 2015b. Antihyperglycemic and antihyperlipidemic effects of Ferula assa-foetida and Ferula tenuissima extracts in diabetic rats. Pak. J. Biol. Sci. 18, 314-323. 
[55] Yusufoglu, H.S., Soliman, G.A., Abdel-Rahman, R.F., Abdel-Kader, M.S., Genaie, M.A., Zhang, H., Hu, J., 1987. Anti-inflammatory and immunopharmacological effect of Xinjiang Ferula oil. Chin. Pharmacol. Bull. 5: 288-290.

[56] Zhang, H., Lu, J., Zhou, L., Jiang, L., Zhou, M., 2015. Antioxidant and antitumor effects of Ferula sinkiangensis K. M. Shen. Int. J. Clin. Exp. Med. 8: 20845-20852.

[57] Znati, M., Jabrane, A., Hajlaoui, H., Harzallah-Skhiri, F., Bouajila, J., Casanova, J,. Jannet, H.B., 2012. Chemical composition and in vitro evaluation of antimicrobial and anti-acetylcholinesterase properties of the flower oil of Ferula lutea. Nat. Prod. Commun. 7: 947-950.

[58] Znati, M., Jannet, H.B., Cazaux, S., Souchard, J.P., Skhiri, F.H., Bouajila, J., 2014. Antioxidant, 5lipoxygenase inhibitory and cytotoxic activities of compounds isolated from the Ferula lutea flowers. Molecules 19: 16959-16975.

[59] Znati, M., Filali, I., Jabrane, A., Casanova, J., Bouajila, J., Ben Jannet, H., 2017. Chemical composition and in vitro evaluation of antimicrobial, antioxidant and antigerminative properties of the seed oil from the Tunisian endemic Ferula tunetana Pomel ex Batt. Chem. Biodivers. 14.human colon cancer cell lines. Phytother. Res. 19:152-157.

Citation: P. Estekhdami, A. Nasiri Dehsorkhi, "Chemical Composition of Volatile Oil of Ferula Assafoetida L" International Journal of Research Studies in Agricultural Sciences (IJRSAS), 2019; 5(8), pp. 9-14, http://dx.doi.org/10.20431/2454-6224.0508002

Copyright: (C) 2019 Authors. This is an open-access article distributed under the terms of the Creative Commons Attribution License, which permits unrestricted use, distribution, and reproduction in any medium, provided the original author and source are credited. 